\title{
Microbial Qualities of Nkwuaku and Ogbaru Streams Located in Awgu Local Government Area in Enugu State, Nigeria
}

\author{
Osita Gabriel Appeh ${ }^{1, *}$, Tochukwu Frank Egwuatu ${ }^{2}$, Chiamaka Maryann Ogbunta ${ }^{1}$ \\ ${ }^{1}$ Department of Microbiology, College of Natural Science, Michael Okpara University of Agriculture Umudike, P.M.B. 7267, \\ Umuahia, Abia State, Nigeria \\ ${ }^{2}$ Department of Cell Biology and Genetics, Faculty of Science, University of Lagos, Akoka-Yaba Lagos State, Nigeria \\ Corresponding author* \\ ositaappeh@yahoo.com
}

Manuscript received: 02 August, 2020. Revision accepted: 06 November, 2020. Published: 22 November, 2020.

\begin{abstract}
Water samples from Nkwuaku and Ogbaru streams located in Awgu local government area in Enugu State, Nigeria were evaluated for the presence of microbial contaminants. Both samples were subjected to physicochemical analysis, total bacterial count and isolation of microbial pathogens, using conventional techniques. Physicochemical characteristics of both water samples showed that Nkwuaku stream had the least total dissolved solid value of $210 \mathrm{mg} / \mathrm{L}$ while the highest value of $270 \mathrm{mg} / \mathrm{L}$ was recorded for Ogbaru stream. Total heterotrophic bacteria count revealed that Ogbaru stream water sample had a higher bacterial population of $5.1 \times 10^{7} \mathrm{cfu} / \mathrm{ml}$ than $\mathrm{Nkwuaku}$ stream water sample which had a bacterial population of $4.2 \times 10^{7} \mathrm{cfu} / \mathrm{ml}$. A total number of twelve (12) microorganisms were isolated from both water samples analyzed. Eight (8) bacteria genera isolated include: Escherichia coli, Enterococcus faecalis, Salmonella spp., Klebsiella spp., Staphylococcum aureus, Pseudomonas aeruginosa, Proteus spp. and Campylobacter spp. Four (4) fungi were isolated and they include: Aspergillus niger, Aspergillus flavus, Aspergillus fumigatus and Fusarium oxysporum. Escherichia coli, Salmonella spp., Staphylococcus aureus and Proteus spp. had the highest percentage occurrence (16.66\%) each while Enterococcus faecalis, Klebsilla spp., Pseudomonas aeruginosa and Campylobacter spp. had the least percentage occurrence (8.33\%) each. Also, Aspergillus recorded the highest percentage occurrence of $40 \%$ for fungi while the least percentage (20\%) was recorded for Aspergillus niger, Fusarium oxysporium and Aspergillus fumigatus each. This study reveals that microbial qualities of these streams render them unfit for human consumption as sources of portable water although they can be used for other household purposes.
\end{abstract}

Keywords: Microorganisms; Contaminants; Physicochemical; Pathogens; Streams.

\section{INTRODUCTION}

Water is the most vital element among the natural resources; it is the most indispensable need for existence of all living things. Its decreasing availability in terms of quality and quantity has been a major public health concern in Africa, particularly in Nigeria (WHO, 2004; Saraveanan and Peter, 2009). According to a recent UNICEF report, about 80 million people in Asia and Africa are living without access to safe water. Consequently, this has caused many people to suffer from various diseases (Tanwir et al., 2003). In developing countries such as Nigeria, most of the rural community lack access to potable water supply and rely mainly on river and stream sources for their household use and other purposes (Banwo, 2006).

Many water sources in developing countries are unhealthy because they contain harmful physical, chemical and biological agents. Unfortunately, many of the available water sources are not potable without some form of treatment which is seldom or not available in most rural settings which expose the rural populace to waterborne diseases (Oketola et al., 2006). In some rural areas in Nigeria, domestic wastes, sewage and faeces are discharged into streams which also serve as their water sources for daily needs. When the load of organic matter or wastes is too heavy, the self-purification power of the stream are unable to remove these materials added and there will be pollution of these water sources which can be dangerous to human and the environment as a whole (Adetokunbo and Grilles, 2003). The microbiological quality of drinking water is of a great primary importance, and the monitoring of bacterial indicators such as total coliform. Microbial indicators have been used worldwide to indicate if human wastes have contaminated water body. Microbes typically utilized are those that are found in elevated concentrated in human faecal coliform, Escherichia coli and Enterococci (Brooks et al., 2006).

An additional indicator, Clostridium perfringes can be used for monitoring stream water quality (Egberongbe et al., 2010). The outbreaks of diarrhea or gastroenteritis in rural communities have all been attributed to the consumption of water of poor microbial 
quality (Ashbolt, 2004). It is therefore not an option but an imperative to critically monitor the quality of water supply in rural areas in order to further highlight their despicable water supply situation and to provide the impetus for sustainable government intervention (Gucker et al., 2006). The aim of this study was to evaluate the microbial qualities of Nkwuaku and Ogbaru streams located in Awgu Local Government Area in Enugu State, Nigeria.

\section{MATERIALS AND METHODS}

\section{Study Area}

The study took place in Awgu Local Government Area of Enugu State, Nigeria. The Local Government is made up of towns such as Agbogugu, Isu-Awa, Ituku, Ihe, Ogbaku, Owelli, Ogugu, Agbudu, Amoli, Mmaku, Ugbo, Obeagu, Mgbidi, Ugwueme, Nkwe, Ezere, Awugu, Nenwenta, Awgunta and Mgbowo. It has clay and stony lands with hilly topography. Subsistence farming, petty trading, livestock rearing, palm wine tapping and stone quarrying are the major occupation of the people. There is no notable industry located in this area and its environs.

\section{Collection of Samples}

Water samples for this study were collected from two different streams (Nkwuaku and Ogbaru) within the study area. The samples were collected in sterile containers at different collection points and analyzed within 24 hours for physicochemical and bacteriological qualities.

\section{Sterilization of Materials}

All glassware which were used for this study were properly washed and rinsed using distilled water and sterilized in a hot air oven at $250^{\circ} \mathrm{C}$ for 1 hour. These glassware included glass Petri-dishes, test tubes, pipette, Bijou bottles and McCartney bottles.

\section{Determination of Physicochemical Characteristics of the Sample}

The physicochemical properties which were examined included temperature, $\mathrm{pH}$, taste, turbidity, colour, conductivity, odour, total solids, total dissolved solids, total suspended solids, acidity and alkalinity.

\section{Determination of pH, Temperature and Conductivity}

The $\mathrm{pH}$ was determined using a $\mathrm{pH}$ meter (HI96107 HANNA pH Meter), which was standardized with a neutral buffer solution of $\mathrm{pH} 7.0$ in a beaker. A $100 \mathrm{ml}$ aliquot of each sample was measured into a beaker and the $\mathrm{pH}$ probe was immersed into the sample. This was allowed for some minutes until a stable reading was obtained, and value was recorded. An aliquot of $50 \mathrm{ml}$ of each sample was measured into a $100 \mathrm{ml}$ beaker and a simple mercury-in-glass thermometer calibrated in degrees centigrade immersed in the water. The reading on the thermometer for each sample was recorded. Conductivity of the two samples was determined using a digital conductivity meter (4520JENWAY, Serial No. 01263). The meter was turned on and allowed to warm up for about 15 minutes. It was then standardized with $0.01 \mathrm{M} \mathrm{KCl}$ solution where a conductivity value of 1413 microsiemen per-centimetre was obtained. The electrode was thoroughly rinsed with distilled water, wiped and then dipped into $100 \mathrm{ml}$ of each water sample in the beaker and left for some minutes to obtain a stable reading. The value for each sample was recorded.

\section{Determination of Colour and Turbidity}

Colour was determined immediately each sample arrived the laboratory. This was carried out after the two samples had been allowed to rest on a bench to attain room temperature. Approximately $25 \mathrm{ml}$ of water from each of the samples was measured into the sample cell for colour analysis. Colour instrument (HACH DR/890) was zeroed with $25 \mathrm{ml}$ distilled water before samples were determined and the readings were recorded. Approximately $10 \mathrm{ml}$ of distilled water was measured into the sample cell of a turbidity meter (HANNA, LP2000), which was used to zero the instrument. Later, $10 \mathrm{ml}$ each from samples was measured into the same cell and the readings were recorded.

\section{Determination of Total Solids (TS) and Total Dissolved Solids by Gravimetric Method}

Total solids were determined as the residues left after evaporation of the unfiltered samples. Approximately $10 \mathrm{ml}$ of each of the two unfiltered samples was taken and evaporated in an evaporating dish in an oven at a temperature of $103-105^{\circ} \mathrm{C}$ for two and half hours. The evaporating dish was then cooled in desiccators and weighed. Total dissolved solids were determined as the residues left after evaporation of the filtered samples, approximately $10 \mathrm{ml}$ of filtered sample from each of the samples was measured into a pre-weighed evaporating dish. The residues collected were then dried in an oven at temperature of $103-105^{\circ} \mathrm{C}$ for one hour and final weights were taken after cooling the evaporating dish in a desiccator.

Total solids were calculated using the formula given below:

$$
\text { Total solids }(\mathrm{mg} / \mathrm{L})=\frac{\left(W_{1}-W_{2}\right) \times 1000}{V}
$$

Where:

$W_{1}$ : Initial weight of dried residue + dish in $\mathrm{mg}$

$W_{2}$ : Final weight of the dish in $\mathrm{mg}$

$V \quad$ : Volume of sample used in $\mathrm{ml}$

\section{Determination of Total Suspended Solids (TSS)}

For total suspended solid (TSS), 10ml each of the water samples were filtered through a pre-weighed filtered 
paper. The filtered papers were dried at $103-105^{\circ} \mathrm{C}$ in oven and TSS was determined by the following formula.

$\operatorname{TSS}(\mathrm{mg} / \mathrm{L})=\frac{\text { Filter post weight }- \text { filter pre weight } \times 1000}{\text { Volume of sample }(\mathrm{ml})}$

\section{Determination of Alkalinity and Acidity}

To $100 \mathrm{ml}$ of each of the water samples, 3 drops of phenolphthalein indicator was added. The samples were titrated with $0.02 \mathrm{~N} \mathrm{H}_{2} \mathrm{SO}_{4}$ to $\mathrm{pH} 8.3$ and phenolphthalein alkalinity was estimated (phenolphthalein indicator was changed colour from pink to colourless at $\mathrm{pH}$ 8.3). Finally, the phenolphthalein alkalinity of water was calculated as follows:

$$
\text { Alkalinity }(\mathrm{mg} / \mathrm{L})=\frac{A \times N \times 50 \times 1000}{V}
$$

Where:

$$
\begin{array}{ll}
A & \text { : Volume of } \mathrm{H}_{2} \mathrm{SO}_{4} \text { in ml } \\
N & \text { : Normality of } \mathrm{H}_{2} \mathrm{SO}_{4} \text { used to titrate } \\
V & \text { : Volume of sample used in ml }
\end{array}
$$

\section{Determination of Acidity}

To $100 \mathrm{ml}$ of each of the water samples, 3 drops of methyl orange indicator was added. The samples were titrated with $0.02 \mathrm{~N}$ standard $\mathrm{NaOH}$ to $\mathrm{pH}$ 8.3. (Methyl orange indicator was changed colour from orange-red to yellow at $\mathrm{pH}$ 8.3). The acidity of water was calculated as follows:

$$
\operatorname{Acidity~}(\mathrm{mg} / \mathrm{L})=\frac{A \times N \times 50 \times 1000}{V}
$$

Where:

$\begin{array}{ll}A & : \text { Volume of } \mathrm{NaOH} \text { titrant used in } \mathrm{ml} \\ N & : \text { Normality of } \mathrm{NaOH} \text { used } \\ V & : \text { Volume of sample used in } \mathrm{ml}\end{array}$

\section{Microbiological Analysis}

\section{Preparation and Inoculation of Samples}

Serial dilution of each sample was made in sterile distilled water by inoculating $1 \mathrm{ml}$ of each sample into the first test tube containing $9 \mathrm{ml}$ of distilled water. The solution was mixed thoroughly and $1 \mathrm{ml}$ of it was transferred into the second test tube containing $9 \mathrm{ml}$ of distilled water. The procedure was repeated with all the remaining tubes. $0.1 \mathrm{ml}$ was pipetted out from $10^{5}$ of the diluted factor and was inoculated in the plate using spread plate technique. The plates were incubated for 24 hours at $25^{\circ} \mathrm{C}$ for bacterial isolation and at $20^{\circ} \mathrm{C}$ for 3 days for fungal isolate using Potato Dextrose Agar. The number of colonies were counted and recorded for both bacteria and fungi.

\section{Purification of Isolates}

The resulting colonies from the Nutrient Agar Medium, MacConkey, Potato Dextrose Agar, Eosin Methyl Blue
Agar, Manitol salt agar, Blood Agar and Salmonella Shigella Agar plates were purified by sub-culturing on freshly prepared nutrient agar plates. The plates were incubated at $25^{\circ} \mathrm{C}$ for 24 hours for bacterial incubation and $20^{\circ} \mathrm{C}$ for 3 days for fungi. After the appropriate periods of incubation, the resulting discrete colonies were transferred onto agar slants in McCartney bottles and kept in the refrigerator as stock culture for subsequent tests during identification.

\section{Characterization and Identification of Bacterial Isolates}

Bacterial isolates were analyzed based on morphological features, Gram staining and other biochemical characterization which included citrate, indole, catalase, coagulase, motility, oxidase, urease, glucose, lactose, fructose and mannitol tests. Confirmation of biochemically characterized bacteria was made using the most Probable Number (MPN) technique.

\section{Identification of Fungal Isolates}

Fungal isolates were identified based on their colonial morphology and cell morphology.

A small portion of fungal growth was isolated with a sterile wireloop and placed on a grease free glass slide and teased with a drop of distilled water. A drop of lactophenol cotton blue stain was added and covered with a greased free cover slip. The slide was observed using $\mathrm{x} 10$ and $\mathrm{x} 40$ objective lenses. Lactophenol cotton blue wet mount preparation is the most widely used method of staining and observing fungi.

\section{RESULTS}

Table 1 shows the various physicochemical characteristics exhibited by the stream water samples. Ogbaru stream had higher colour value of $10 \mathrm{HU}$ than Nkwuaku stream which had a colour value of $6 \mathrm{HU}$. Nkwuaku stream sample had no objectionable odour while Ogbaru stream sample had an objectionable odour. Nkwuaku stream had a lower $\mathrm{pH}$ value of 6.7 while Ogbaru had a $\mathrm{pH}$ value of 8.3. Turbidity was higher in Ogbaru stream and lower in Nkwuaku stream sample. Ogbaru stream had a higher temperature of $27^{\circ} \mathrm{C}$ than Nkwuaku $\left(26^{\circ} \mathrm{C}\right)$. Conductivity was higher in Ogbaru stream sample $(678 \mu \mathrm{s} / \mathrm{cm})$ than in Nkwuaku stream sample $(468 \mu \mathrm{s} / \mathrm{cm})$. The value for total solids was lower $(430 \mathrm{mg} / \mathrm{l})$ in Nkwuaku stream and higher $(530 \mathrm{mg} / \mathrm{l})$ in Ogbaru sample. Nkwuaku sample recorded a lower total dissolved solids $(210 \mathrm{mg} / \mathrm{l})$ than Ogbaru (270 mg/l). Total suspended solids was $220 \mathrm{mg} / \mathrm{l}$ in Nkwuaku stream and $260 \mathrm{mg} / \mathrm{l}$ in Ogbaru stream sample. Ogbaru stream sample's acidity was $4.0 \mathrm{mg} / \mathrm{l}$ and that of Ogbaru stream was $6.0 \mathrm{mg} / \mathrm{l}$. Alkalinity was recorded to be $5.0 \mathrm{mg} / \mathrm{l}$ in Ogbaru sample and $6.0 \mathrm{mg} / \mathrm{l}$ in Nkwuaku sample. 
Table 1. Physicochemical Characteristics of the Stream Water Samples in Awugu Local Government Area, Enugu State.

\begin{tabular}{lll}
\hline Parameters & $\begin{array}{l}\text { Sample A } \\
\text { Nkwuaku } \\
\text { Stream }\end{array}$ & $\begin{array}{l}\text { Sample B } \\
\text { Ogbaru } \\
\text { Stream }\end{array}$ \\
\hline $\mathrm{pH}$ & 6.7 & 8.3 \\
Temperature $\left({ }^{\circ} \mathrm{C}\right)$ & 26 & 27 \\
Conductivity $(\mu \mathrm{s} / \mathrm{cm})$ & 468 & 678 \\
Colour $(\mathrm{HU})$ & 6.0 & 10.0 \\
Turbidity $(\mathrm{NTU})$ & 8.0 & 10.0 \\
Odour & $\mathrm{U}$ & $\mathrm{O}$ \\
Total solids $(\mathrm{mg} / \mathrm{l})$ & 430 & 530 \\
Total dissolved solids $(\mathrm{mg} / \mathrm{l})$ & 210 & 270 \\
Total suspended solids $(\mathrm{mg} / \mathrm{l})$ & 220 & 260 \\
Alkalinity(mg/l) & 6.0 & 5.0 \\
Acidity(mg/l) & 4.0 & 6.0 \\
\hline
\end{tabular}

Key: $\mathrm{U}=$ Unobjectionable; $\mathrm{O}=$ Objectionable; $\mathrm{HU}=$ Hazen Unit; NTU = Naphelometric Turbidity Unit.
Table 2 shows the colonial characteristics of each isolates on Nutrient agar, Eosin methylene blue agar, MacConkey agar, Manitol salt agar, Salmonella-shigella agar and Blood agar. The isolates which were obtained include staphylococcus aureus, Enterococcus faecalis, Escherichia coli, Salmonella Species, Klebsiella species, Pseudomonas aeruginosa, Proteus species and Campylobacter species.

Table 3 shows the total bacterial and fungal plate counts of the stream samples. The total bacteria count revealed that Ogbaru stream had a higher total bacteria count of $5.1 \times 10^{7} \mathrm{cfu} / \mathrm{ml}$ than Nkwuaku stream which had $1.2 \times 10^{7} \mathrm{cfu} / \mathrm{ml}$. This indicates that Nkwuaku stream sample had the lower bacterial indicators compared with Ogbaru stream sample. Also, the total fungal count revealed that Nkwuaku had a higher total fungi count $\left(4.0 \times 10^{7} \mathrm{cfu} / \mathrm{ml}\right)$ than Ogbaru stream $\left(1.6 \times 10^{7}\right.$ $\mathrm{cfu} / \mathrm{ml})$.

Table 2. Colonial Characteristics of Isolates from Ogbaru and Nkwuaku Stream Water on Different Growth Media.

\begin{tabular}{|c|c|c|c|c|c|c|}
\hline \multirow{2}{*}{$\begin{array}{l}\text { Isolate } \\
\text { Code }\end{array}$} & \multicolumn{6}{|c|}{ Media Plates } \\
\hline & NA & EMB & MAC & MSA & SSA & BA \\
\hline OG1 & $\begin{array}{l}\text { Smooth, golden } \\
\text { yellow, convex } \\
\text { colonies }\end{array}$ & - & $\begin{array}{l}\text { Pink, smooth, } \\
\text { convex and opaque } \\
\text { colonies }\end{array}$ & $\begin{array}{l}\text { Yellow, smooth, } \\
\text { convex and } \\
\text { opaque colonies }\end{array}$ & - & $\begin{array}{l}\text { Light golden } \\
\text { yellow, smooth, } \\
\text { convex and } \\
\text { hemolytic colonies }\end{array}$ \\
\hline OG2 & $\begin{array}{l}\text { Thick, grayish } \\
\text { white, moist, } \\
\text { smooth \& opaque } \\
\text { colonies }\end{array}$ & $\begin{array}{l}\text { Green metallic } \\
\text { sheen smooth } \\
\text { colonies }\end{array}$ & $\begin{array}{l}\text { Moist, smooth, flat } \\
\& \text { pink colonies }\end{array}$ & - & $\begin{array}{l}\text { Slight growth } \\
\text { pink colonies }\end{array}$ & $\begin{array}{l}\text { Gray, moist \& } \\
\text { hemolytic colonies }\end{array}$ \\
\hline OG3 & $\begin{array}{l}\text { Low convex, } \\
\text { smooth, grayish } \\
\text { white translucent } \\
\text { colonies }\end{array}$ & - & $\begin{array}{l}\text { Low convex, } \\
\text { smooth, colourless } \\
\text { and transparent } \\
\text { colonies }\end{array}$ & - & $\begin{array}{l}\text { Black colonies } \\
\text { with offensive } \\
\text { odour }\end{array}$ & $\begin{array}{l}\text { Low convex, } \\
\text { smooth, grayish } \\
\text { white, translucent } \\
\text { and non-hemolytic } \\
\text { colonies }\end{array}$ \\
\hline OG4 & $\begin{array}{l}\text { Irregular, low } \\
\text { convex, smooth, } \\
\text { mucoid, greenish } \\
\text { yellow opaque } \\
\text { colonies }\end{array}$ & $\begin{array}{l}\text { Metallic sheen } \\
\text { and glass } \\
\text { appearance } \\
\text { colonies }\end{array}$ & $\begin{array}{l}\text { Low convex, } \\
\text { smooth, mucoid, } \\
\text { colourless } \\
\text { transparent } \\
\text { colonies }\end{array}$ & - & $\begin{array}{l}\text { Irregular slight } \\
\text { growth \& nearly } \\
\text { colorless } \\
\text { colonies }\end{array}$ & $\begin{array}{l}\text { Flat, smooth, } \\
\text { mucoid, grayish } \\
\text { white, opaque, } \\
\text { hemolytic colonies }\end{array}$ \\
\hline NK1 & $\begin{array}{l}\text { Whitish, round } \\
\text { raised, glistering } \\
\text { colonies }\end{array}$ & $\begin{array}{l}\text { Light pink } \\
\text { raised large } \\
\text { colonies }\end{array}$ & - & Yellow colonies & - & $\begin{array}{l}\text { White non- } \\
\text { hemolytic colonies }\end{array}$ \\
\hline NK2 & $\begin{array}{l}\text { Mucoid, grayish } \\
\text { white, raised } \\
\text { opaque colonies }\end{array}$ & $\begin{array}{l}\text { Convex, } \\
\text { mucoid, pink } \\
\text { translucent } \\
\text { colonies }\end{array}$ & $\begin{array}{l}\text { Convex, mucoid, } \\
\text { pink-red opaque } \\
\text { colonies }\end{array}$ & - & $\begin{array}{l}\text { Smooth slight } \\
\text { growth, pink } \\
\text { colonies }\end{array}$ & $\begin{array}{l}\text { Mucoid, grayish } \\
\text { white, opaque non- } \\
\text { hemolytic colonies }\end{array}$ \\
\hline NK3 & $\begin{array}{l}\text { Smooth, opaque, } \\
\text { irregular, } \\
\text { glistening grayish } \\
\text { white translucent } \\
\text { colonies }\end{array}$ & $\begin{array}{l}\text { Glistening, } \\
\text { colourles, } \\
\text { transparent } \\
\text { colonies }\end{array}$ & $\begin{array}{l}\text { Low convex, } \\
\text { smooth, colourless } \\
\text { transparent } \\
\text { colonies }\end{array}$ & - & $\begin{array}{l}\text { Colorless with } \\
\text { black center } \\
\text { colonies }\end{array}$ & $\begin{array}{l}\text { Irregular, } \\
\text { glistening, grayish } \\
\text { white, opaque, } \\
\text { non-hemolytic } \\
\text { colonies }\end{array}$ \\
\hline NK4 & $\begin{array}{l}\text { Whitish droplet } \\
\text { colonies }\end{array}$ & - & - & - & - & $\begin{array}{l}\text { Smooth, grayish, } \\
\text { convex, glistening } \\
\text { \& non-hemolytic } \\
\text { colonies }\end{array}$ \\
\hline
\end{tabular}

- = No growth; NA = Nutrient Agar; EMB = Eosin Methylene Blue agar; MAC = MacConkey Agar; MSA = Manitol Salt Agar;

$\mathrm{SSA}=$ Salmonella - Shigella Agar; BA = Blood Agar; OG = Ogbaru; NK = Nkwuaku. 
Table 3. Total Bacterial and Fungal Plate Counts Obtained from the Stream Water Samples.

\begin{tabular}{|c|c|c|c|c|c|}
\hline \multirow[t]{2}{*}{ Sample Source } & \multicolumn{4}{|c|}{ Bacteria $(\mathrm{Cfu} / \mathrm{ml})$} & \multirow{2}{*}{$\begin{array}{l}\text { Fungi (cfu/ml) } \\
\text { PDA }\end{array}$} \\
\hline & NA & EMB & MAC & SSA & \\
\hline Nkwuaku & $4.2 \times 10^{7}$ & $2.8 \times 10^{7}$ & $3.9 \times 10^{7}$ & $2.2 \times 10^{7}$ & $4.0 \times 10^{7}$ \\
\hline Ogbaru & $5.1 \times 10^{7}$ & $1.5 \times 10^{7}$ & $3.5 \times 10^{7}$ & $1.9 \times 10^{7}$ & $1.6 \times 10^{7}$ \\
\hline
\end{tabular}

PDA = Potato Dextrose Agar; NA = Nutrient Agar; EMB = Eosin Methylene Blue agar; MAC = MacConkey agar; SSA = Salmonella Shigella Agar

Table 4 shows various groups of microorganisms isolated and identified from this study. They include; Staphylococcus aureus, Escherichia coli, Enterococcus faecalis, Klebsiella pneumonia, Proteus spp, Pseudomonas aeruginosa, Salmonella spp. and Campylobacter spp.

Table 4. Morphological and Biochemical Characteristics of Bacteria Present in Stream Water Samples in Awgu Local Government Area, Enugu.

\begin{tabular}{|c|c|c|c|c|c|c|c|c|c|c|c|c|c|c|}
\hline 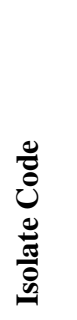 & 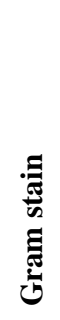 & $\frac{\Xi}{\tilde{E}}$ & 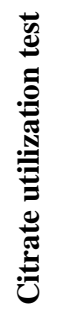 & 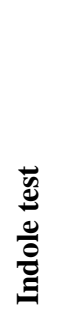 & 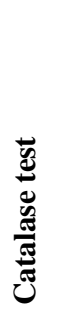 & 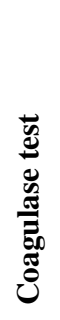 & 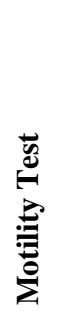 & 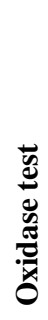 & 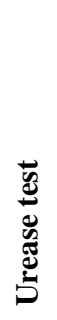 & 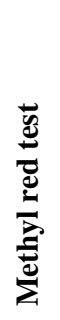 & 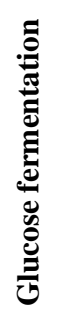 & 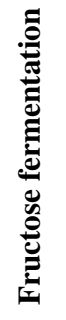 & 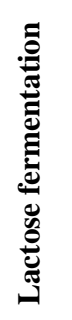 & 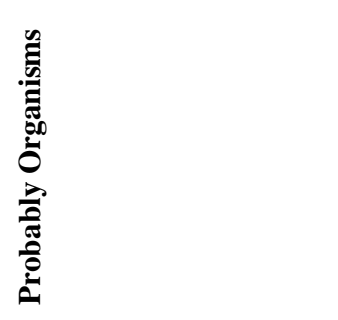 \\
\hline $\mathrm{OG}_{1}$ & + & Cocci & - & - & + & + & + & - & - & + & $\mathrm{AG}$ & NA & $\mathrm{AG}$ & Staphylococcus aureus \\
\hline $\mathrm{OG}_{2}$ & - & Rod & - & + & - & - & + & - & - & - & AG & AG & AG & Escherichia coli \\
\hline $\mathrm{OG}_{3}$ & - & Rod & - & - & - & - & + & - & - & + & $\mathrm{AG}$ & NA & NA & Salmonella spp \\
\hline $\mathrm{OG}_{4}$ & _ & Rod & - & - & - & - & + & + & - & - & AG & AG & AG & Pseudomonas aeruginosa \\
\hline $\mathrm{NK}_{1}$ & + & Cocci & + & - & - & - & - & - & - & - & AG & AG & AG & Enterococcus faecalis \\
\hline $\mathrm{NK}_{2}$ & - & Rod & + & - & - & - & - & - & + & + & NAG & AG & AG & Klebsiella spp. \\
\hline $\mathrm{NK}_{3}$ & _ & Rod & - & - & - & - & + & - & + & - & $\mathrm{AG}$ & AG & NA & Proteus spp \\
\hline $\mathrm{NK}_{4}$ & - & Spiral & - & - & + & - & + & + & - & + & NA & NA & NA & Campylobacter spp. \\
\hline
\end{tabular}

$+=$ positive; $-=$ Negative; $\mathrm{AG}=$ Acid and Gas production; NA = No Acid production; NAG = No Acid and Gas production;

$\mathrm{OG}=$ Ogbaru; $\mathrm{NK}=$ Nkwuaku .

Table 5. Morphological Characteristics of Fungal Isolates in the Stream Water Samples.

\begin{tabular}{lll}
\hline Macroscopy & Microscopy & Organism(s) \\
\hline $\begin{array}{l}\text { Dark-brown } \\
\text { mycelium }\end{array}$ & $\begin{array}{l}\text { Conidiophores smooth } \\
\text { walked and non-septate }\end{array}$ & $\begin{array}{l}\text { Aspergillus } \\
\text { niger }\end{array}$ \\
$\begin{array}{l}\text { Yellow pink } \\
\text { creamy }\end{array}$ & $\begin{array}{l}\text { Cylindrical to ovoid } \\
\text { conidia, curved septate } \\
\text { colonies }\end{array}$ & $\begin{array}{l}\text { Fusarium } \\
\text { oxysporum }\end{array}$ \\
$\begin{array}{l}\text { Light green and } \\
\text { powdery }\end{array}$ & $\begin{array}{l}\text { Long, erect septate, } \\
\text { conidiophores }\end{array}$ & $\begin{array}{l}\text { Aspergillus } \\
\text { flavus }\end{array}$ \\
$\begin{array}{l}\text { Gray-green } \\
\text { fluggy colonies }\end{array}$ & $\begin{array}{l}\text { Long, erect, non-septate } \\
\text { conidiophores }\end{array}$ & $\begin{array}{l}\text { Aspergillus } \\
\text { fumigatus }\end{array}$ \\
\hline
\end{tabular}

Table 5 shows various fungi isolates and identified from the stream samples by their morphological characteristics. They are; Aspergillus niger, Fusarium oxysporum, Aspergillus flavus and Aspergillus fumigatus.
Table 6 shows the result of the MPN tests for occurrence of the presumptive coliforms $(E$. coli). The result revealed a gross coliform contamination in the two stream samples.

Table 6. MPN Values per $100 \mathrm{ml}$ of the Stream Water Samples.

\begin{tabular}{lcccc}
\hline & \multicolumn{5}{c}{ No. of Tubes Giving a Positive Result } \\
Water Samples & $\mathbf{5}$ of & $\mathbf{5}$ of & $\mathbf{5}$ of & MPN \\
& $\mathbf{1 0 m l}$ & $\mathbf{1 m l}$ & $\mathbf{0 . 1 m l}$ & (Per 100ml) \\
\hline Nkwuaku Stream & 0 & 1 & 0 & 2 \\
& 1 & 1 & 0 & 4 \\
& 1 & 0 & 1 & 4 \\
Ogbaru Stream & 1 & 1 & 1 & 6 \\
& 1 & 0 & 0 & 2 \\
& 2 & 0 & 0 & 5 \\
& 2 & 0 & 1 & 7 \\
& 3 & 1 & 0 & 11 \\
& 1 & 1 & 1 & 6 \\
& 0 & 2 & 0 & 4 \\
\hline
\end{tabular}

MPN $($ Per $100 \mathrm{ml})=$ Most Probable Number per $100 \mathrm{ml}$ of water sample. 
Table 7 shows the percentage occurrence of bacterial isolates from the stream water samples which includes; Escherichia coli, 2(16.66\%); Enterococcus faecalis 1(8.33\%); Salmonella spp. 2(16.66\%); Klebsiella spp. 1(8.33\%); Staphylococcus aureus 2(16.66\%); Pseudomonas aeruginosa 1(8.33\%); Proteus spp. 2(16.66\%) and Campylobacter spp. 1(8.33\%).

Table 7. Percentage Occurrence of Bacterial Isolates from Stream Water Samples.

\begin{tabular}{llll}
\hline S/N & Isolates & $\begin{array}{l}\text { Frequency } \\
\text { Occurrence }\end{array}$ & $\begin{array}{l}\% \\
\text { Occurrence }\end{array}$ \\
\hline 1. & Escherichia coli & 2 & $16.66 \%$ \\
2. & Enterococcus faecalis & 1 & $8.33 \%$ \\
3. & Salmonella spp. & 2 & $16.66 \%$ \\
4. & Klebsiella spp. & 1 & $8.33 \%$ \\
5. & Staphylococcus aureus & 2 & $16.66 \%$ \\
6. & Pseudomonas & 1 & $8.33 \%$ \\
& aeruginosa & 2 & $16.66 \%$ \\
7. & Proteus spp. & 2 & $8.33 \%$ \\
8. & Campylobacter spp. & 1 & $100 \%$ \\
\hline & & 12 & \\
\hline
\end{tabular}

Table 8 shows the percentage occurrence of fungi isolates from stream water samples. They are; Aspergillus niger 1(20\%); Aspergillus flavus 2(40\%); Fusarium oxysporum 1(20\%) and Aspergillus fumigatus $1(20 \%)$.

Table 8. Percentage Occurrence of Fungal Isolates from Stream Water Samples.

\begin{tabular}{llll}
\hline S/N & Isolates & $\begin{array}{l}\text { Frequency } \\
\text { Occurrence }\end{array}$ & $\begin{array}{l}\% \\
\text { Occurrence }\end{array}$ \\
\hline 1. & Aspergillus niger & 1 & $20.0 \%$ \\
2. & Aspergillus flavus & 2 & $40.0 \%$ \\
3. & Fusarium oxysporum & 1 & $20.0 \%$ \\
4. & Aspergillus fumigatus & 1 & $20.0 \%$ \\
\hline & & 5 & $100 \%$ \\
\hline
\end{tabular}

\section{DISCUSSION}

Evaluation of microbial contamination of Nkwaku and Ogbaru streams showed that the $\mathrm{pH}$ of Nkwaku stream sample was 6.7 while that of Ogbaru sample was 8.3. This is in agreement with $\mathrm{pH}$ assigned by the US Environmental Protection Agency (EPA) as the standard $\mathrm{pH}$ of water which ranges from 6.5 - 8.5 (EPA, 2002). The higher $\mathrm{pH}$ values measured from the stream samples could be attributed to more rain water deposition which dilutes the acidity of water by raising the $\mathrm{pH}$. Thus indicated that the measured $\mathrm{pH}$ values of the stream samples were within permissible value which will not cause any harmful effect to the consumers.

Ogbaru stream sample had a higher temperature value $\left(27^{\circ} \mathrm{C}\right)$ than Nkwaku sample $\left(26^{\circ} \mathrm{C}\right)$ and this could be attributed to the fact the samples were collected early in the morning. This conforms with the findings of Okoye and Umo (2006) who stated that cool water are generally more potable for drinking, because high water temperature enhances the growth of microorganisms and causes taste, odour, colour and corrosion problems.

In the case of turbidity, Ogbaru sample recorded higher value of 10 NTU while Nkwuaku recorded a lower value of 8 NTU. The obtained values are far greater than the value specified and approved (5NTU) by the World Health Organization (WHO) (WHO, 2004). The higher values obtained could have been caused by rainfall and human activities such as; grazing of ruminants and improper management of solid and liquid wastes within the streams. High turbidity is also associated with high levels of disease causing microorganisms such as bacteria, fungi and other parasites. Thus, waters from these streams are not good for drinking purpose.

The total dissolved solid (TDS) of the samples are in agreement with the EPA standard of $500 \mathrm{mg} / \mathrm{L}$. Ogbaru recorded higher value of $260 \mathrm{mg} / \mathrm{L}$ while a lower value of $210 \mathrm{mg} / \mathrm{L}$ was recorded in Nkwuaku sample. Odour of Nkwaku sample was perceived to be unobjectionable whereas the odour of Ogbaru sample was objectionable. The objectionable odour of Ogbaru sample could be due to the presence of aquatic lives (fungi, bacteria etc) and waste disposal from toilets, industries, household etc. and this makes the water unfit for drinking.

The percentage occurrence of bacterial and fungal isolates from the stream samples were determined and the result revealed that Escherichia coli, Salmonella spp., Staphylococcus aureus and Proteus spp. recorded the highest percentage occurrence $(16.66 \%)$ while Enterococcus faecalis, Klebsiella spp., Pseudomonas aeruginosa and Campylobacter spp. recorded lower percentage occurrence $(8.33 \%)$.

The high number of Salmonella, Proteus spp and Staphylococcus aureus in the stream samples are not in agreement with EPA water standard for recreational use which states that these pathogenic organisms must not be present in water, because they are of public health significance, having been associated with gastrointestinal infections, diarrhoea, typhoid fever and other form of infection (EPA, 2005).

The total bacteria and fungi counts for the two samples were generally high, exceeding the limit of 1.0 $\mathrm{x} 10^{2} \mathrm{cfu} / \mathrm{ml}$ which is the standard limit of heterotrophic count for drinking water (EPA, 2002). This indicates the presence of high organic matters and nutrient sources which supported the growth of the microbes. The primary sources of microbial contamination include the surface runoff, sewage treatment facilities and improper management activities of the inhabitants like washing, refuse dumping, open defaecatio and dropping of different materials into water bodies.

Various groups of microorganisms were isolated and identified during the study. They include Escherichia 
coli, Staphylococcus aureus, Enterococcus faecalis, Klebsiella pnueumonia, Proteus sp, Pseudomonas aeruginosa, Salmonella spp. and Campylobacter spp. for bacteria. The fungi isolated include Aspergillus niger, Fusarium oxysporum, Aspergillus flavus and Aspergillus fumigatus. The presence of some of these organisms signifies contamination of water from domestic sources. The Staphylococcus species are known to produce enterotoxins (Okonko et al., 2008). Proteus species are intestinal flora, but also widely distributed in soils and water (Sclegel, 2002). Pseudomonas aeruginosa is an example of non-faecal coliforms, while E. coli is a faecal coliform.

\section{CONCLUSION}

From this study it can be observed that from the microbial qualities of these that they are unfit for human consumption though they can be used for other purposes. Many of the inhabitants of Awgu Local Government Area depend on these two streams for drinking water supplied. In view of this, it is recommended that the Government should ban and discourage all indiscriminate disposal of wastes within stream environments.

Conflict of interest: The author declares that there are no conflicts of interest concerning the publication of this article.

\section{REFERENCES}

Adetokunbo, D. and Gilles, F. (2003). World Health Organization (WHO) guidelines on the quality of drinking water. The environmentalist 20:25-56.

Ashbolt, N. J. (2004). Microbial contamination of drinking water and disease outcomes in developing regions. Toxicology 198:229-238

Banwo, K. (2006). Nutrient Load and Pollution Study of some selected stations along Ogunpa River in Ibadan, Nigeria. African Journal of Microbiology 25:7-11.
Brooks, B.W., Riley, T.M. and Taylor, R. D. (2006). Water quality of effluent dominated ecosystem: ecotoxicological, hydrological and management considerations Hydrobiologia $556: 379$.

Egberongbe, H.O., Awoderu, V.A. and Bello, O.O. (2010) Microbial and Physicochemical evaluation of some streams along Ilisan-Ago-Iwoye road, Ogun state, Nigeria. Journal of Olabisi Onabanjo University. Microbiology Applied Zoology and plant science 1-10.

EPA (2002). US Environmental Protection Agency, Safe Drinking Water Act Amendment http://www.epa.gov/safewater/mc/.html.

EPA (2005). "Protecting Water Quality from Agricultural Runoff'. Fact Sheet No.EPA-841-F-05-001.

Gucker, B., Brauns, M. and Pusch, M.T. (2006). Effect of waste water treatment plant discharge on ecosystem structure and function of lowland streams. The Environmentalist 25:313329.

Oketola, A. A., Osibanjo, O., Ejelonu, B. C., Oladimeji, Y. B. and Danazio, O. A. (2006). Water quality assessment of river Ogun around the cattle market of Isheri, Nigeria. Journal of Applied Science 6:511-517.

Okonko, I. O., Adejoye, O. D., Ogunsi, T. A., Fajobi, E. A. and Shittu, O.B. (2008). Microbiological and Physicochemical Analysis of Different Water Samples used for Domestic Purposes in Abeokuta and Ojota, Lagos State, Nigeria. African Journal of Biotechnol. 7(5): 617-621.

Okoye, C. O. B. and Umo, A. E. (2006). Quality of borehole water in Nsukka Area, Enugu State, Nigeria, Nig. Annals Natr. Scs., 6(2), 121-123.

Saravanan, S. and Peter, M. (2009). Water pollution and man health. Centre for Development Research. Germany. Pp 1-5.

Sclegel, H.G. (2002). General Microbiology. $7^{\text {th }}$. Ed. Cambridge University Press. 480.

Tanwir, F. A., Saboor, M.H. and Shan, A. (2003). Water contamination, health hazards and public awareness: a case of the urban puijab, Pakistan. International Journal of Agriculture and Biology. 5: 460-462.

WHO (2004). Water Sanitation and Health Programme. Managing water in the home: accelerated health gains from improved water sources. Flourosis and Sanitation 11:7-11. 
THIS PAGE INTENTIONALLY LEFT BLANK 